\title{
Cytotoxicity and Anticancer Activity of Donkioporiella mellea on MRC5 (Normal Human Lung) and A549 (Human Lung Carcinoma) Cells Lines
}

\author{
Anith M. M. Sairi, ${ }^{1}$ Siti Izera Ismail, ${ }^{1}$ Arina Sukor, ${ }^{2}$ Noraswati M. N. Rashid, ${ }^{3}$ \\ Norsazilawati Saad, ${ }^{1}$ Syari Jamian, ${ }^{1}$ and Sumaiyah Abdullah ${ }^{1}{ }^{1}$ \\ ${ }^{1}$ Department of Plant Protection, Faculty of Agriculture, Universiti Putra Malaysia, 43400 UPM Serdang, Selangor, Malaysia \\ ${ }^{2}$ Department of Land Management, Faculty of Agriculture, Universiti Putra Malaysia, 43400 UPM Serdang, Selangor, Malaysia \\ ${ }^{3}$ Agro-Biotechnology Institute Malaysia (ABI) Complex, Jalan Eksotika Off Persiaran MARDI-UPM, Serdang, \\ Seri Kembangan 43400, Selangor, Malaysia
}

Correspondence should be addressed to Sumaiyah Abdullah; sumaiyah@upm.edu.my

Received 16 July 2020; Revised 13 November 2020; Accepted 27 November 2020; Published 9 December 2020

Academic Editor: Gihyun Lee

Copyright (c) 2020 Anith M. M. Sairi et al. This is an open access article distributed under the Creative Commons Attribution License, which permits unrestricted use, distribution, and reproduction in any medium, provided the original work is properly cited.

\begin{abstract}
Polypores are mushrooms which are rich in bioactivities and for generations, they have been widely used as herbal remedies. Despite their significant importance in treatments of various health issues, only a few local species have been reported for their pharmacological potentials. The present study was carried out to establish cytotoxicity potentials of Donkioporiella mellea, a local polypore species collected from forested areas in Malaysia at cellular levels on normal human lung (MRC5) and human lung carcinoma (A549) cell lines. Survival and inhibition rates were analyzed by 3-(4, 5)-dimethylthiahiazo (-z-y-l)-2,5-diphenyltetrazoliumbromide (MTT) while monitoring changes on cellular shapes by inverted phase contrast microscopy. Survival rates of MRC5 cells were observed to be significantly higher than A549 after treatments with various concentrations of polypore extracts. MRC5 cells showed excellence in survival performance when treated with hot and cold aqueous extracts. Cold aqueous extract showed higher cytotoxicity activities compared to hot aqueous extract $\left(p<0.0001\right.$ ) with inhibitory concentration $\left(\mathrm{IC}_{50}\right.$ ) values of $414.29 \mu \mathrm{g} / \mathrm{ml}$ and $>1000 \mu \mathrm{g} / \mathrm{ml}$, respectively. Treatments with tamoxifen as a control exhibited necrotic features in both cell lines. The results suggest that $D$. mellea possesses pharmacological potentials that can be utilized for human consumption as a new bioresource alternative, thus encouraging research advancement in mycological and nutraceutical studies.
\end{abstract}

\section{Introduction}

Malaysia is a megadiverse country with flora and fauna of great biodiversity. Literature has it that tropical climate is the most favorable habitat for diverse species of polypores. Lee et al. [1] listed 4000 species of fungi found mostly from divisions or phyla Ascomycota and Basidiomycota. Estimated at about $70 \%$ of macrofungi, these phyla have not been described and discussed [2]. Much of the information and knowledge on the abundance of macrofungi diversity are either outdated or scattered in many different publications and not readily available [2] or already out of print [1].
Numerous Basidiomycetes or commonly known as mushrooms are natural decomposers, which are pathogens or parasites having symbiotic relationships with both animals and plants. Edible mushrooms are always high in worldwide demand as reflected by their annual increase in production [3]. They have unique and subtle savor which made them popular in gourmet cuisines throughout the world $[4,5]$. Since the dawn of time, besides having good flavor favored by many, mushrooms have also been, for centuries, routinely used as remedies by indigenous Chinese. Abundant bioactive compounds with antioxidants properties have been widely cited [6-8]. Europe, five popularly 
known polypore mushrooms, sometimes known as European ancestors' heritage, include Laetiporus sulphureus, Fomes fomentarius, Fomitopsis pinicola, Piptoporus betuli$n u s$, and Laricifomes officinalis [9]. In Asian countries such as Japan, Korea, and China, the species Phellinus linteus has been regarded as a traditional Chinese medicine with a 2000year-long history of being used in medicinal applications for treatments of hemorrhages, hemostasis, and disease related to female menstruation $[10,11]$. Several medicinal species of mushrooms endowed with medicinal properties such as Ganoderma lucidum, Lignosus rhinocerotis (tiger milk mushroom), Lentinus spp., Hericium erinaceum (monkey head mushroom), Termitomyces spp., Schizophyllum spp. and others have also been well documented. However, evaluations on their pharmacological potentials are still advancing with some exhibiting high market prospects.

Natural products from biological organisms have served as favorable and affordable sources for new drug entities. These natural products have led to the development of numerous vaccines and other medicinal products [12]. However, some organisms, including mushrooms, are known to be poisonous to humans and animals, by virtue of the organisms' natural survival and defense system to sustain in the environment. Against this background, cytotoxicity study is important as a primary step in determining the potentials of biologically active compounds isolated from these organisms [13]. In the pharmaceutical or cosmetic industries, cytotoxicity study is considered a standard of procedure to establish toxicity level of any new drugs or products. Successful development of new discovery is dependent on these toxicity results, either minimal or nontoxic. In this regard, studies in cellular toxicity play a crucial role as a way of introducing new variety of edible organisms which are safe for human consumption and have the potential of exploiting their therapeutic components.

Edibility of mushrooms is based on such criteria as being nonpoisonous, desirable taste and aroma [14], and unique texture [15]. These mushrooms are known as culinary mushrooms [16]. Edible mushrooms are mainly consumed for their nutritional or dietary benefits. However, advances in research have discovered that mushrooms have metabolites that are medically significant and have been utilized for their anticancer, antimicrobial, antioxidant, immunomodulatory, antihypersensitive $[17,18]$, antiatherosclerotic, and anticarcinogenic properties $[19,20]$. For this reason, edible mushrooms are those that can be consumed as either culinary-medicinal mushrooms or edible-medicinal mushrooms [16]. However, not all medicinal mushrooms are readily edible due to hard texture of their fruiting bodies. These types of mushrooms are consumed in the form of powdered extract. There are several poisonous mushrooms that had been reported such as Entoloma rhodopolium and Scleroderma citrinum which are known to cause rhabdomyolysis and gastrointestinal distress in animals and humans $[16,21]$. The primary purpose of the present study was to introduce a new species of local polypore mushroom establishing its cytotoxic efficacy at the cellular level with a view of promoting further research and development of mushrooms research advances in Malaysia.

\section{Materials and Methods}

2.1. Reagents. Reagents used in the present study included the following: RPMI 1640 (Rosewell Park Memorial Institute) medium (from Gibco), phosphate buffer saline (from PBS-Sigma), Pen-strep (Penicillin-Streptomycin Antibiotic, (from Gibco), fungizone (from Gibco), fetus bovine serum (from FBS-Gibco), MTT (3-(4, 5)-dimethylthiahiazo (-z-y-1)-2, 5-diphenyltetrazoliumbromide), DMSO (Dimethyl Sulfoxide), Tamoxifen, and trypsin with phenolic red (with $0.05-0.25 \%$ ) (from Gibco).

\subsection{Sample Preparation and Mycelium Accumulation.} Polypore mushroom specimens were collected from forested areas in Kepong, Selangor, Malaysia in April 2018 during a dry season. The sample was isolated for pure culture and deposited at the Agro-Biotechnology Institute (ABI) collection deposit centre with a voucher code ABI002. The mushroom species, Donkioporiella mellea, was identified by mycologist (ABI) through morphological and molecular methods. The sequences obtained from the specimens were submitted to a GenBank database, an open access, annotated collection of all publicly available nucleotide sequences and their protein translations. The accession number was MT229067. Ten plugs of mycelia from agar culture were transferred into flasks containing $100 \mathrm{ml}$ of mushroom complete medium (MCM) with some modifications. The flasks were placed on a rotary shaker and run at $150 \mathrm{rpm}$ at $28^{\circ} \mathrm{C}$ for 14 days. Subsequently, the mycelia and culture broth were harvested and kept in a $-80^{\circ} \mathrm{C}$ freezer overnight and dried by freeze-drying (Labconco freeze-dry machine) for 3 days. Mycelium biomass were mashed into fine powder for further extraction process.

2.3. Preparation of Extract. In the present study, the extraction procedures used were by hot and cold aqueous extraction methods. Double-distilled water was used as a solvent throughout the extraction processes.

2.3.1. Hot Aqueous Extraction. The extraction method procedure was adopted from a previous study by Lee et al. [22] with some modifications. Ten grams of mycelium powder were boiled in a $200 \mathrm{ml}$ of double-distilled water in a ratio of $1: 20$ with temperature ranging from $90^{\circ} \mathrm{C}$ to $95^{\circ} \mathrm{C}$ for 20 to 30 minutes. The samples were subsequently centrifuged at $8000 \times \mathrm{g}$ for 15 minutes and the supernatant was filtered using Whatman No.1 filter paper. The residues were reextracted with $100 \mathrm{ml}$ of distilled water. The filtrate from two rounds of extractions were combined and dried by freeze-drying. The extract obtained and stored at $4^{\circ} \mathrm{C}$ was used directly for evaluation of cytotoxicity.

2.3.2. Cold Aqueous Extraction. The extraction method for cold aqueous extract was adapted from Tseng and Mau [23]. The ratio of mycelium sample to double-distilled water was $1: 10$. Ten grams of mycelium powder was added to $100 \mathrm{ml}$ of distilled water in a $500 \mathrm{ml}$ flask while shaking vigorously. The 
flask containing the sample mixture was let to stand while stirring at $100 \mathrm{rpm}$ for 24 hours at room temperature $\left(25^{\circ} \mathrm{C}\right)$. Subsequently, the mixture was centrifuged at $5000 \times \mathrm{g}$ for 15 minutes and the supernatant was filtered through Whatman No. 1 filter paper. The residue was reextracted by adding $100 \mathrm{ml}$ of distilled water. The filtrates from two rounds of extractions were combined and freeze-dried. The extract obtained was stored at $4^{\circ} \mathrm{C}$ and used directly for cytotoxicity evaluation.

\subsection{Cell Viability}

2.4.1. Cell Culture. Cell culture and assay protocols were conducted in a biosafety cabinet Class 2. Two types of cell lines were used: MRC5 (normal human lung fibroblast) and carcinoma human lung epithelial (A549) previously obtained from American Type Culture Collection (ATCC). These cells were cultured in RPMI-1640 (Rosewell Park Memorial Institute) medium supplemented with $10 \%$ of fetal bovine serum (FBS), 1\% of pen-strep (penicillin streptomycin), and $0.5 \%$ of fungizone. Both cells types were cultured in an incubator set at $37^{\circ} \mathrm{C}$ and humidified with $5 \%$ of $\mathrm{CO}_{2}$ atmosphere. All cells were cultured in 2-day intervals. Growth responses were observed on a daily basis under an inverted microscope. Only cells at their exponential growth were used throughout the experiments.

2.4.2. Treatment Application. Solutions of fresh extract were prepared by dissolving extracts of $D$. mellea with sterile distilled water while tamoxifen was used as a control. All mixtures of extracts were filtered using $0.22 \mathrm{~nm}$ filter membrane before transferring them into 96-well plates containing the two cell lines. Precisely, an amount $1 \times 10^{4}$ of cell concentrations were seeded in each well for 24 hours before treatment application of treatments. Cells in each of the 96-well plate were treated with different concentrations gradient of samples mixture from $1.95 \mu \mathrm{g} / \mathrm{ml}$ to $1 \mathrm{mg} / \mathrm{ml}$ for different times of exposure $(24,48$, and 72 hours). The procedure was done in three replications.

2.4.3. MTT Assay. Cell viability was determined through MTT bioassay protocols adopted from Mosmann [24]. Following incubation in different concentrations of samples, an amount of $15 \mathrm{mg}$ of MTT powder was weighed and diluted in $3 \mathrm{ml}$ of phosphate-buffered saline (PBS) solution to obtain a concentration of $5 \mathrm{mg} / \mathrm{ml}$. The MTT solution was filtered using $0.22 \mathrm{~nm}$ filter membrane into a Petri dish. Treated plates were retrieved from the incubator and $20 \mu \mathrm{l}$ MTT solution was pipetted into each well. The plates were reincubated in an incubator for 4 hours after which the solution was discarded leaving only the purple formazan crystals. An amount of $100 \mu \mathrm{l}$ DMSO was added into all wells to dissolve the purple formazan crystals by gently resuspending until completely dissolved. Absorbance of the assay was measured using a microplate reader at $590 \mathrm{~nm}$.
2.4.4. Parameter. Cell performances after treatment were evaluated through proliferation and inhibition rates of the cells. Data were taken at 24-, 48-, and 72-hour intervals. Both proliferation and inhibition parameters were obtained from MTT assay results, based on the following equations:

(1) The proliferation rate of cells (\%)

$$
\frac{(A T-A B)}{(A C-A B)} \times 100 \%,
$$

where ATis the absorbance of treated cells, AB is theabsorbance of blank (media only), and AC is the absorbance of control (untreated cells).

(2) The Inhibition rate of cells or cytotoxicity (\%): = $100-$ total number of survived cells (\%).

2.4.5. Statistical Analysis. All results of the study were expressed as means \pm standard error of mean (SEM). Significance differences were evaluated by Analysis of Variance (ANOVA). A probability level of $p<0.05$ was considered statistically significant. All data were analyzed using SAS (Statistical Analysis System) software version 9.4.

\section{Results and Discussion}

3.1. Toxicity Effect of Different Extracts at Cellular Levels. The proliferation rate of MRC5 cell line treated with hot aqueous extract of $D$. mellea showed no significant changes $(p<0.05)$ as the concentrations were increased. The survival rate was significantly higher, as treatment application times were prolonged up to $72 \mathrm{hr}$ as presented in Table 1. On the contrary, treatment with cold aqueous extract of $D$. mellea showed acute cell inhibition at the highest concentration compared to hot aqueous extract with rate of inhibition being less than $40 \%$ after $72 \mathrm{hr}$ of treatment (Figure 1). However, the $\mathrm{IC}_{50}$ value for both $D$. mellea extracts were more than $1000 \mu \mathrm{g} / \mathrm{ml}$ on MRC5 cell line, suggesting that this mushroom was safe for human consumption. Tamoxifen was used as a positive control. The characteristics of tamoxifen were toxic at cell levels showing lowest survival rate among other treatments in a dose-dependent manner (Figure 1). Although tamoxifen was harmful to MRC5 cell line, the cells still survived at lower concentrations $(1.95,3.9,7.8$, and $15.625 \mu \mathrm{g} / \mathrm{ml}$ ) with survival percentages of $94.4,93.8,79.4$, and $27.5 \%$, respectively. The survival rates for other concentrations were approximately zero. Cell survival rates for other concentrations were recorded to be near zero. As presented in Figure 1, the stability of the reaction between extracts and cells gave an indication of being time-dependent. In some treatments, survival rate slightly increased from 24 to 48 hours of exposure. Exposure for 72 hours recorded significant changes for all treatments, suggesting that exposure at longer time was needed for maximum damage, which, in turn, influenced the stability of samples, and reactions of cells.

Under an inverted microscope, changes in the morphological phase were observed for different treatments after 
TABLE 1: Effects of time of exposures (24, 48, and 72 hours) and different types of extracts (hot aqueous, cold aqueous, and tamoxifen) on $\mathrm{IC}_{50}$ values for cytotoxicity of MRC5 cell lines. Cytotoxicity of extracts on A549.

\begin{tabular}{lccc}
\hline & \multicolumn{3}{c}{ Types of extracts $(\mu \mathrm{g} / \mathrm{ml})$} \\
$\begin{array}{l}\text { Times of exposure } \\
\text { (hour) }\end{array}$ & $\begin{array}{c}\text { Hot } \\
\text { aqueous }\end{array}$ & $\begin{array}{c}\text { Cold } \\
\text { aqueous }\end{array}$ & Tamoxifen \\
& $\mathrm{IC}_{50}(\mu \mathrm{g} / \mathrm{ml})$ & $\mathrm{IC}_{50}(\mu \mathrm{g} / \mathrm{ml})$ & $\mathrm{IC}_{50}$ \\
$(\mu \mathrm{g} / \mathrm{ml})$ \\
\hline 24 & $>1000$ & $>1000$ & 21.42 \\
48 & $>1000$ & $>1000$ & 14.29 \\
72 & $>1000$ & $>1000$ & 10.0 \\
\hline
\end{tabular}

$72 \mathrm{hr}$ of exposure. Normal cells of MRC5 (Figure 2) were observed as fibroblast cells flat, elongated, and spindleshaped (aligned in parallel cluster). The application of hot extract of $D$. mellea did not trigger any morphological changes on the cells. The proliferation rate of cells as well as untreated MRC5 cell growth was satisfactory. For cold extract of $D$. mellea treatment, as the gradient concentrations changed (except at $1000 \mu \mathrm{g} / \mathrm{ml}$ concentration), the cells became thickened and round in shape, but adherent ability remained. Tamoxifen application caused significant variations in cell morphology in a dose-dependent manner where higher doses caused cell lysis and dead cells floating in the medium.

A549 cell line showed lethal effects for all extracts' types of varying concentrations with variations in survival rates. The present study observed that proliferation rate of A549 cell line decreased in a time-dependent manner such that as time duration increased, inhibition rate increased. Cells treated with hot aqueous extract of $D$. mellea were observed to have slower changes in proliferation rate as concentrations were increased. Significant toxicity effect was observed in time-dependent manner, the highest being at the highest concentration $(1000 \mu \mathrm{g} / \mathrm{ml})$ of hot aqueous extract, suggesting that growth of cancer cells could be inhibited by more than $30 \%$ as time was extended using hot aqueous mycelium extract of $D$. mellea at $1000 \mu \mathrm{g} / \mathrm{ml}$ concentration. However, the survival rate of A549 cell line was significantly affected by cold aqueous compared to hot aqueous extract. The proliferation rate of A549 significantly decreased at higher concentrations (500 and $1000 \mu \mathrm{g} / \mathrm{ml}$ ) in a time-dependent manner as shown in Figure 3. The lethal effect of tamoxifen can be seen clearly on how the cells reacted towards different dosages of tamoxifen. Tamoxifen killed the cells directly and effectively compared to $D$. mellea extracts. As shown in Table 2, the $\mathrm{IC}_{50}$ value of tamoxifen was lower than both extracts of $D$. mellea. Cell survival rate decreased as concentration increased across all extracts applications.

Untreated A549 cell line had polygonal shape and remained proliferating to a confluent level (Figure 4). On the other hand, cells treated with different concentrations of both aqueous extracts of $D$. mellea induced obvious morphological changes at the highest concentration. Hot water extract showed some symptoms in separation of cell fragments and in density at $1000 \mu \mathrm{g} / \mathrm{ml}$. Cell density decreased in treatment with $500 \mu \mathrm{g} / \mathrm{ml}$ as compared to the untreated (control). At similar concentrations (500 and $1000 \mu \mathrm{g} / \mathrm{ml}$ ) for cold aqueous extract, the cells progressively shrunk to smaller, rounded shape and some of the cells were observed to be detached. However, at higher concentrations, the separation of cell fragments was observed on cells treated with cold water aqueous compared to hot aqueous extract treatment. At lower concentrations, most cells remained in elongated shape with adherent ability and still attached to the surface of flasks. The majority of A549 cells were completely detrimental, remained detached, and floated in the medium after treatment with tamoxifen at concentrations of 15.625 to $1000 \mu \mathrm{g} / \mathrm{ml}$. Tamoxifen at concentration lower than $15.625 \mu \mathrm{g} / \mathrm{ml}$ caused changes in cell density.

In treatments of less than $72 \mathrm{hr}$ duration, the effects were clearly seen on proliferation and inhibition rates of MRC5 where maximum damage occurred in the cells. The cells responded differently according to treatments. Changes in the effects of cytotoxicity as recorded in the study suggest that MRC5 cells were a toxicity marker at cellular level, as well as an indicator of whether the mushroom was edible and safe for human consumption. The present study also observed that hot aqueous mycelium extract of $D$. mellea was safe for human consumption as the proliferation rate was recorded to be consistent (Figure 1). As concentrations increased, survival rates remained high. However, cold aqueous mycelium extract of $D$. mellea demonstrated low selection ability with acute cytotoxicity at higher concentration $(61.3 \%$ at $1000 \mu \mathrm{g} / \mathrm{ml}$ ) (Figure 1$)$ at which the extract inhibited normal lung cells (MRC5) with 38.7\%. Hot aqueous extract at lower concentrations showed cytostatic effect on A549 cell line at lower concentration but became cytotoxic at the highest concentration. Cold aqueous extract of $D$. mellea showed higher cytotoxicity effect compared to hot aqueous extract. For hot and cold aqueous extracts of D. mellea, cell inhibition of A549 increased as treatment duration was extended. Both extracts showed significant difference $(p<0.05)$ at higher concentrations of aqueous extract of $D$. mellea against A549 cell line. At lower concentration $(15.25 \mu \mathrm{g} / \mathrm{ml})$, tamoxifen yielded necrotic symptoms on MRC5 and A549. Tamoxifen produced the highest rate of inhibition compared to the two different aqueous extracts of $D$. mellea.

As the concentrations were increased, hot aqueous extract induced inhibition effects at moderate level on A549. The findings suggest that hot aqueous extract had low anticancer effect $\left(\mathrm{IC}_{50}>1000 \mu \mathrm{g} / \mathrm{ml}\right)$, possibly due to different pharmacological potential as reported in numerous other studies. Hot aqueous extracts of mushroom have been reported to have copious amount of carbohydrate and protein as high-molecular-weight polysaccharides and polysaccharide-protein complexes but low in fat. This feature sets mushroom as immunomodulatory by modulating immune system in the human body rather than targeting cells directly $[25,26]$. Lai et al. [27] reported that the hot water extract of Polyporus rhinocerus exhibited moderate cytotoxicity against HL-60 $\left(\mathrm{IC}_{50} \sim 1000 \mu \mathrm{g} / \mathrm{ml}\right)$. The reports concurred with Lau et al. [28] who also reported that hot aqueous extract of Lignosus rhinocerotis reduced viability of several cancer cells (A549, MCF7, HL-60, PC3, and HK1) by 50\% after $72 \mathrm{hr}$ 


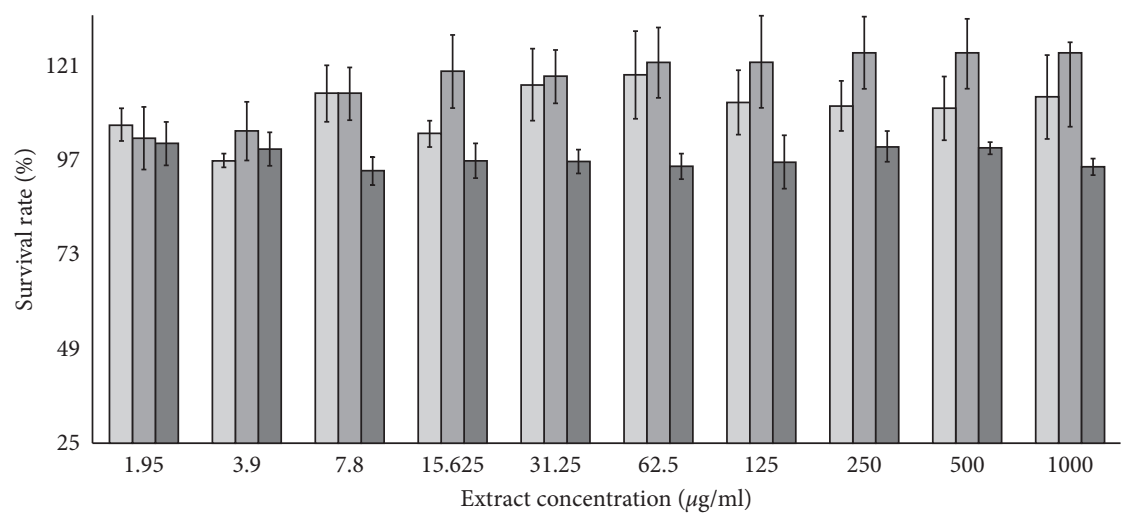

$\square 24 \mathrm{hr}$

$\square 48 \mathrm{hr}$

$\square 72 \mathrm{hr}$

(a)

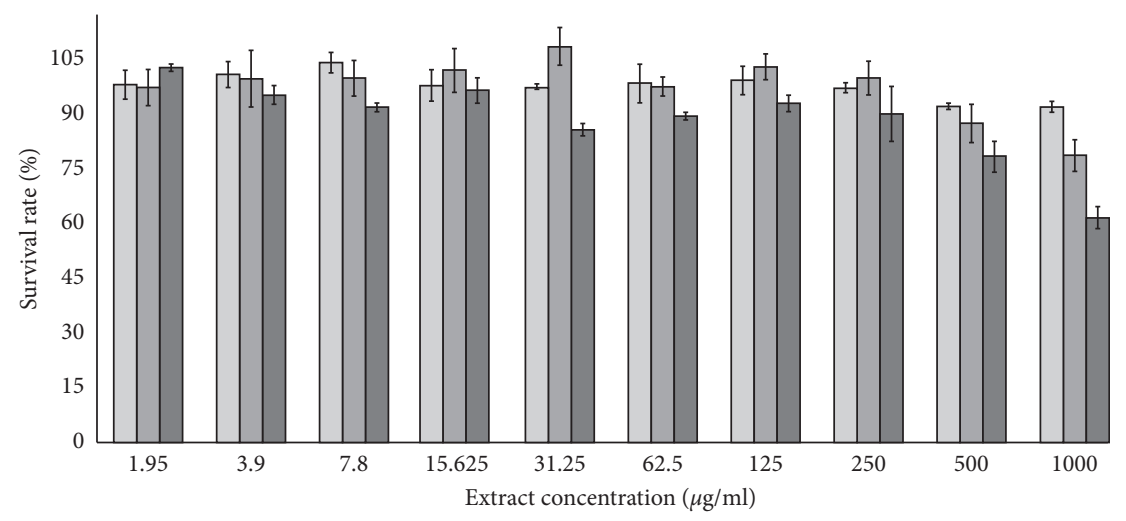

$\square 24 \mathrm{hr}$

$\square 48 \mathrm{hr}$

$\square 72 \mathrm{hr}$

(b)

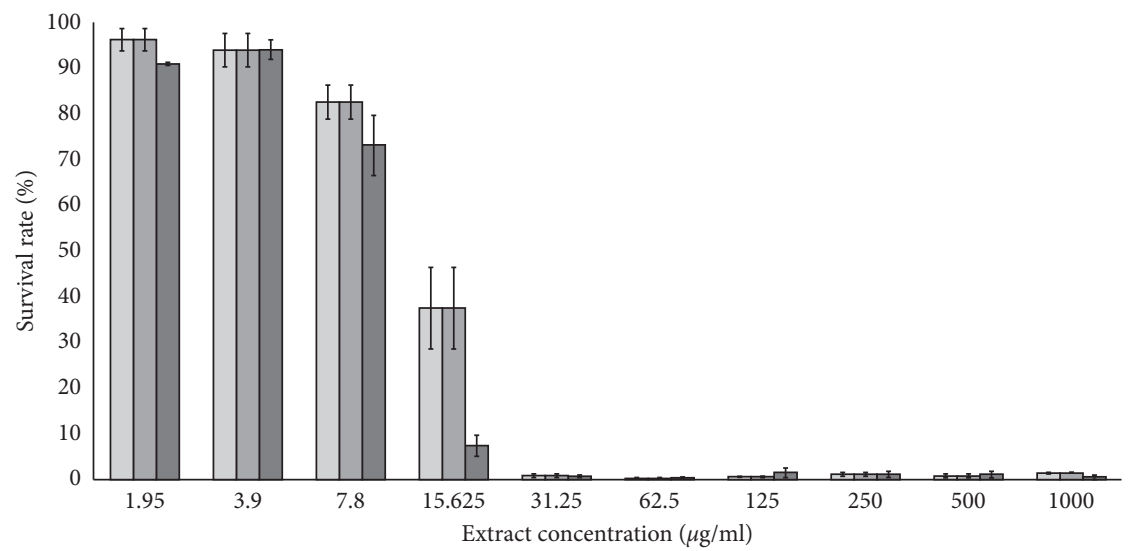

$\square 24 \mathrm{hr}$

$\square 48 \mathrm{hr}$

$\square 72 \mathrm{hr}$

(c)

FIGURE 1: Inhibition effects on MRC5 cells after 24, 48, and $72 \mathrm{hr}$ of time exposure measured by MTT. (a) Survival rates of MRC5 cells treated with different concentrations of hot aqueous extract. (b) Survival rates of MRC5 cells treated with different concentrations of cold aqueous extract. (c) Survival rates of MRC5 cells treated with different concentrations of tamoxifen as control. 


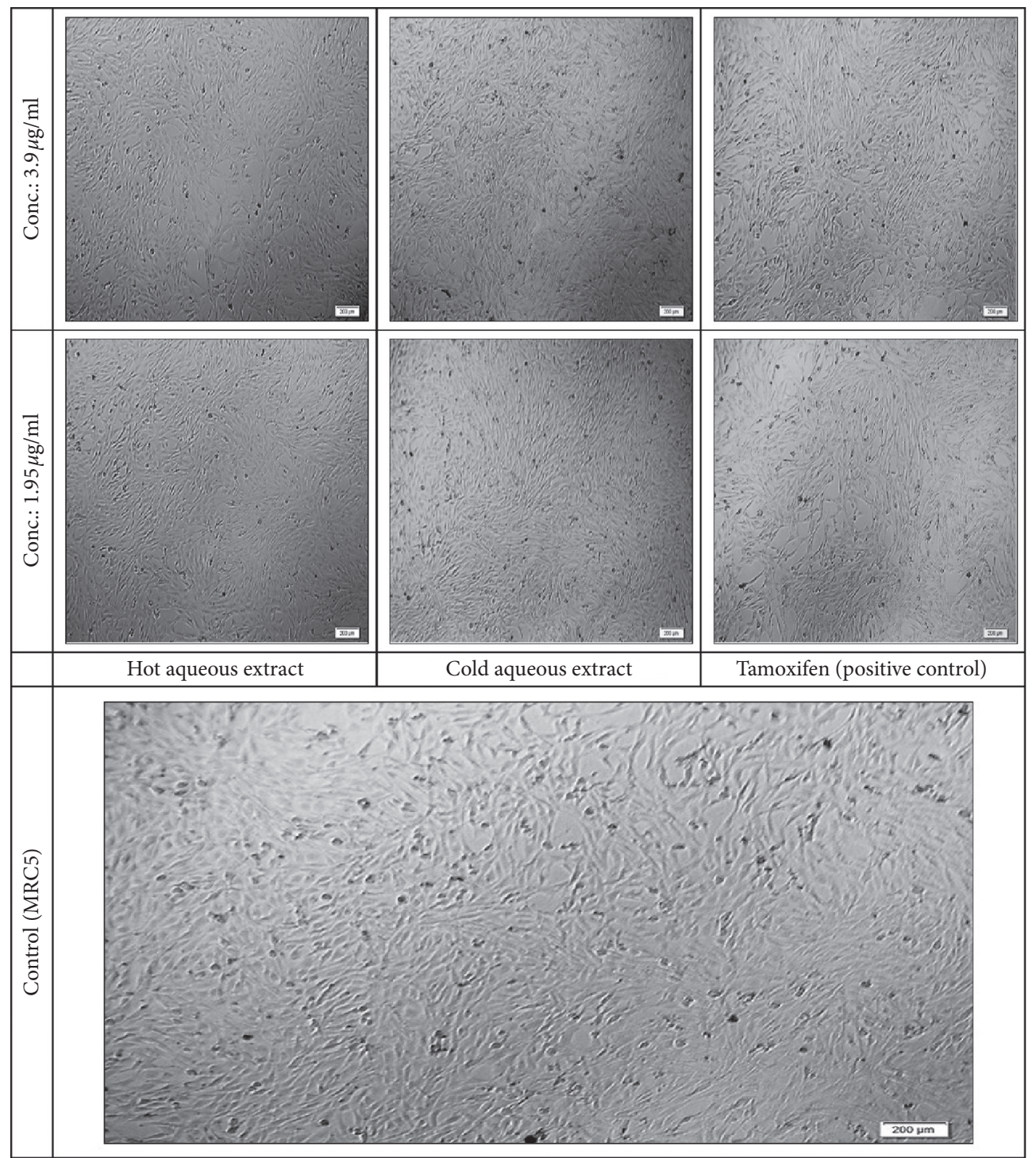

Figure 2: Morphological changes of MRC5 cell after $72 \mathrm{hr}$ treatments induced by hot aqueous extract, cold aqueous extract, and tamoxifen as positive control in concentrations (conc.) of 1.95 to $3.9 \mu \mathrm{g} / \mathrm{ml}$ observed under inverted phase contrast microscopy (20x total magnification). Scale bar: $200 \mu \mathrm{m}$.

duration of treatment exposure at higher concentration. Hot aqueous extracts of mushrooms were proven to be less effective against tumor cells directly unless specific extraction protocol was carried out. Jamil et al. [26] reported that boiled water extract from tuber of L. rhinocerotis had mild cytotoxicity activity against A549 while purification of the extract changed the cytotoxicity level $(57.78 \mu \mathrm{g} / \mathrm{ml})$ of the tuber on the same cell type.

Cold aqueous extract was observed to have good antiproliferation effect on A549 compared to hot aqueous extract with an $\mathrm{IC}_{50}$ value of $414.29 \mu \mathrm{g} / \mathrm{ml}$ (Table 2). The finding was in line with several studies with hispolon-induced apoptosis in lung cancer cells A549 and H66 but different in their levels of cytotoxicity. Ethanol extract from fruiting bodies of Phellinus igniarius had $\mathrm{IC}_{50}$ value of $531.7 \mu \mathrm{g} / \mathrm{ml}$ against A549 but had lower cytotoxicity against SGC-7901 (gastric cancer) with an $\mathrm{IC}_{50}$ value of $110.7 \mu \mathrm{g} / \mathrm{ml}$ [29]. In contrast with previous discoveries, $D$. mellea extract tested in the present study had lower $\mathrm{IC}_{50}$ value suggesting higher level of cytotoxicity activity against A549 cells compared to P. igniarius. However, each mushroom has specific ability against specific tumor cells depending on its bioactive constituents. As an example, total triterpenes of G. lucidum were reported to be highly effective in inhibiting proliferation of MCF7 cells at concentration of $100 \mu \mathrm{g} / \mathrm{ml}$ [30] while polysaccharide extract of the same had immunomodulatory activity [31]. These conflicting findings were likely due to differences in the extraction methods and solvents used in the extraction protocol as differences in chemical composition yielded different outcomes. Nevertheless, the ability of cold aqueous mycelium extract against A549 cell was slower compared to other mushroom types which could be related to bioreactivity at cellular level from different extraction methods and parts of mushrooms sourced. As proven by several other studies, 


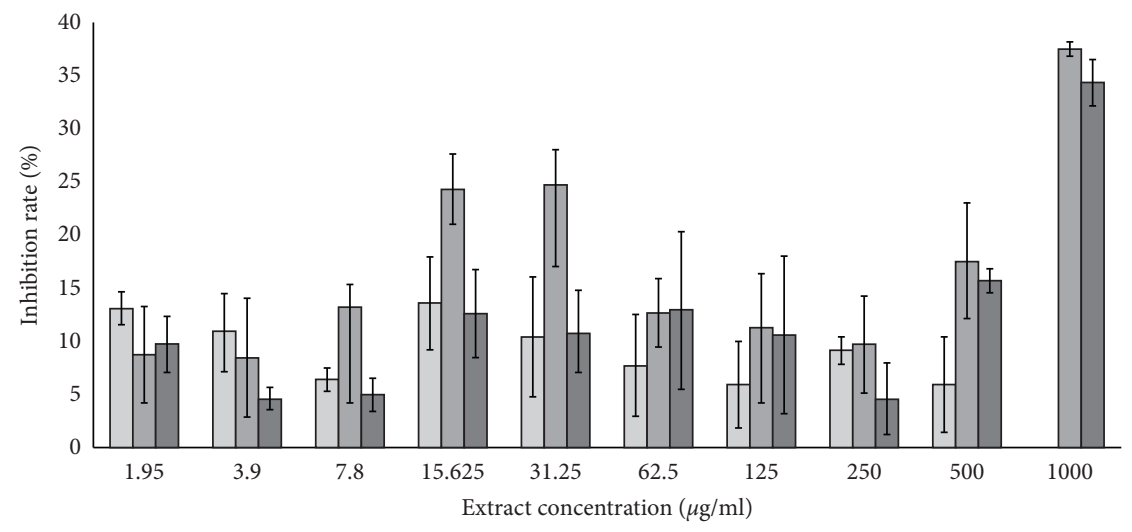

$$
\square 24 \mathrm{hr}
$$

$$
\begin{aligned}
& \square 48 \mathrm{hr} \\
& \square 72 \mathrm{hr}
\end{aligned}
$$

(a)

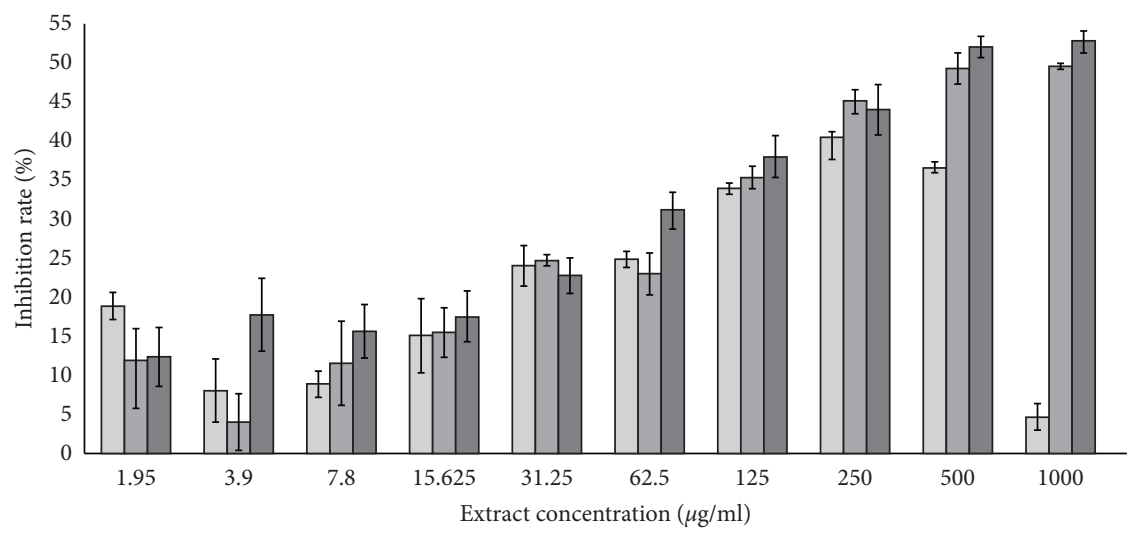

$$
\begin{aligned}
& \square 24 \mathrm{hr} \\
& \square 48 \mathrm{hr} \\
& \square 72 \mathrm{hr}
\end{aligned}
$$

(b)

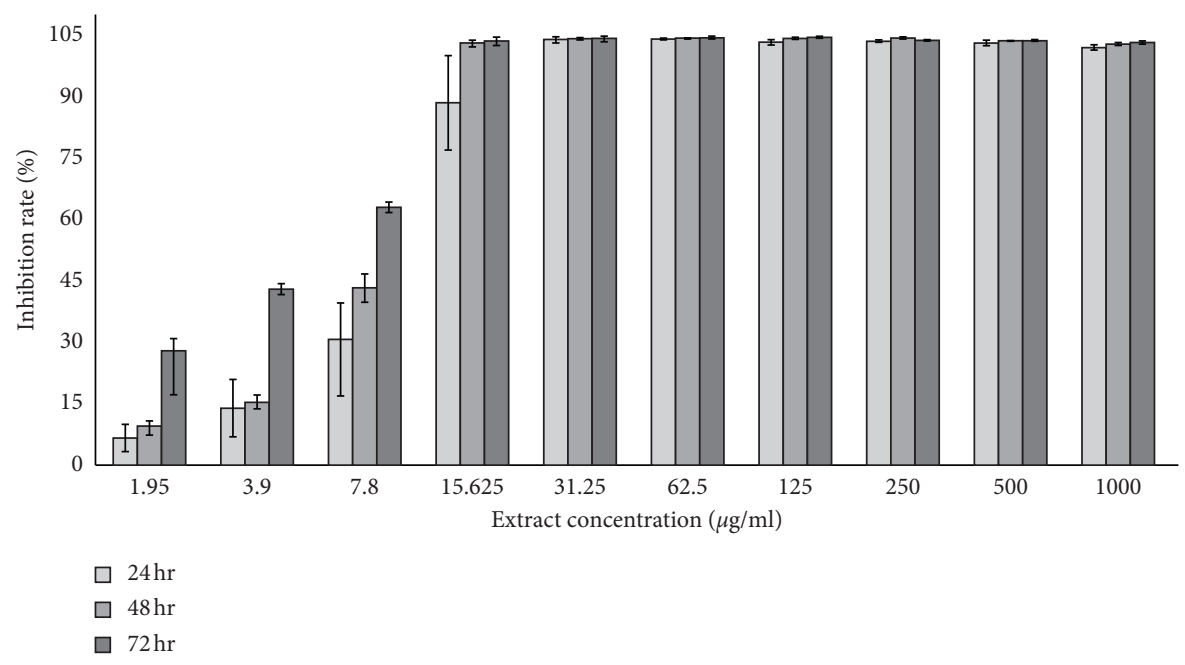

(c)

Figure 3: Cytotoxicity effects on A549 cell lines after 24, 48, and $72 \mathrm{hr}$ measured by MTT. (a) Inhibition rates of A549 cells treated with different concentrations of hot aqueous extract. (b) Inhibition rates of A549 cells treated with different concentrations of cold aqueous extract. (c) Inhibition rate of A549 cells treated with different concentrations of tamoxifen as control. 
TABLE 2: Effects of times of exposure (24, 48, and 72 hours) and different types of extracts (hot aqueous, cold aqueous, and tamoxifen) on $\mathrm{IC}_{50}$ values for cytotoxicity of A549 cell lines.

\begin{tabular}{lccc}
\hline & & Extracts type $(\mu \mathrm{g} / \mathrm{ml})$ \\
Cimes of exposure (hour) & Hot aqueous & $\mathrm{IC}_{50}(\mu \mathrm{g} / \mathrm{ml})$ & $\begin{array}{c}\text { Tamoxifen } \\
\mathrm{IC}_{50}(\mu \mathrm{g} / \mathrm{ml})\end{array}$ \\
\hline 24 & $\mathrm{IC}_{50}(\mu \mathrm{g} / \mathrm{ml})$ & $>1000$ & 11.42 \\
48 & $>1000$ & $>1000$ & 7.14 \\
72 & $>1000$ & 414.29 & 4.2 \\
\hline
\end{tabular}

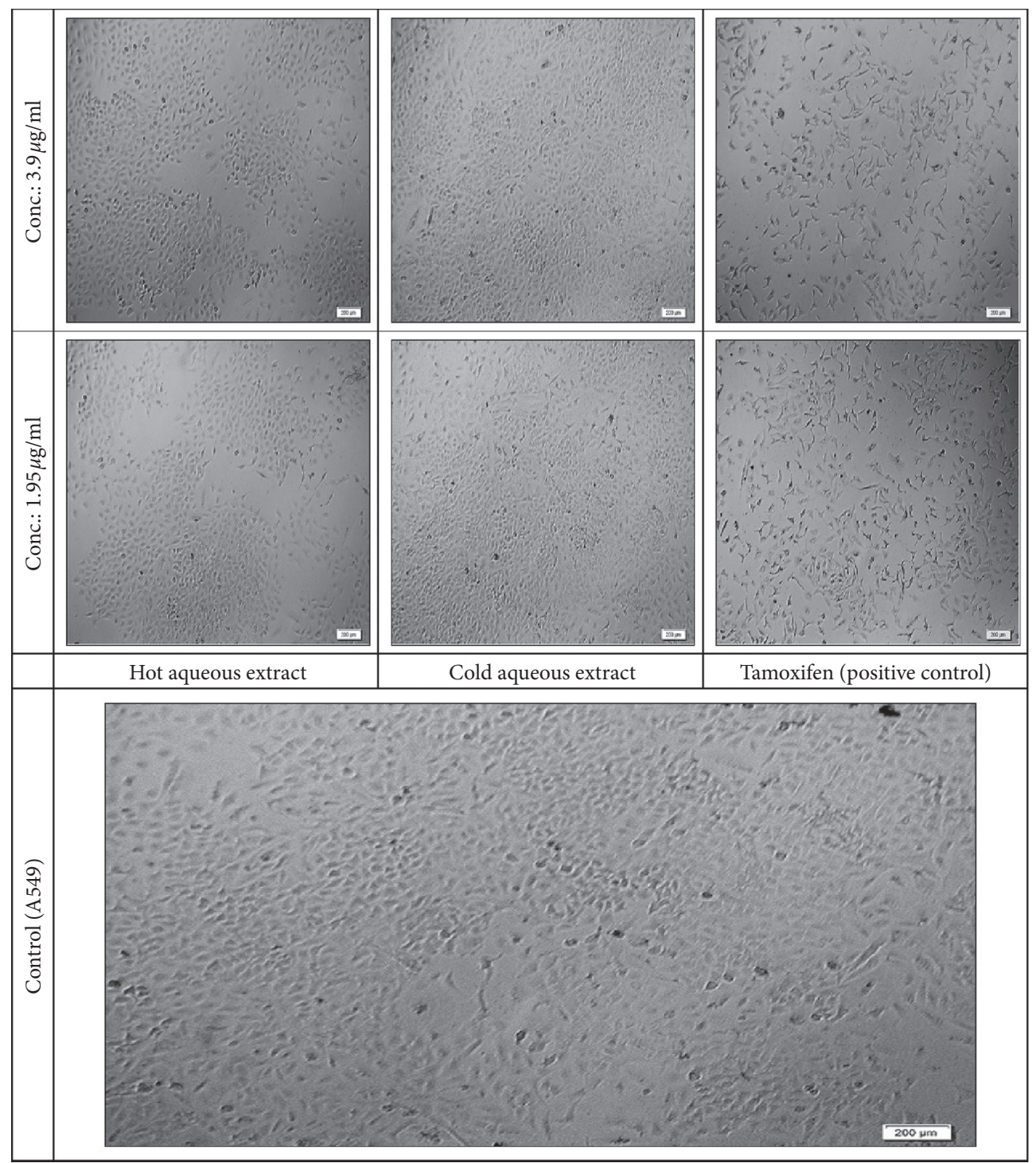

Figure 4: Morphological changes in A549 cells after $72 \mathrm{hr}$ treatments induced by hot aqueous extract, cold aqueous extract, and tamoxifen as positive control in concentrations (conc.) of 1.95 and $3.9 \mu \mathrm{g} / \mathrm{ml}$ observed under inverted phase contrast microscopy (20x total magnification). Scale bar: $200 \mu \mathrm{m}$.

extracts from different parts of mushrooms (such as vegetative part) and harvest stages (different physiological stages) were reported to have different levels of bioactivities [32, 33]. Various cytotoxicity levels in mushrooms against A549 cells have been reported from various sources and extract types such as polysaccharide extract of $F$. fomentarius from fruiting bodies $\left(\mathrm{IC}_{50}: 100 \mu \mathrm{g} / \mathrm{ml}\right.$ ), ethanol extract of sclerotia of Poria $\operatorname{cocos}\left(\mathrm{IC}_{50}: 301.1 \mu \mathrm{g} / \mathrm{ml}\right)$, and aqueous extract of L. rhinocerotis $\left(\mathrm{IC}_{50}: 41.13 \mu \mathrm{g} / \mathrm{ml}\right)[28,34,35]$.

The cytotoxic effect of aqueous extracts of $D$. mellea affected morphological structures of A549 cells in a concentration-dependent manner after $72 \mathrm{hr}$ of treatment exposure. 
At higher concentration of cold aqueous application, A549 cell line became refractile under microscopic observations as the cells progressively shrunk to smaller, rounder shape and started to detach. Some of dead cells were observed to become detached and floated in the medium after treatment of cold aqueous at concentrations of 500 and $1000 \mu \mathrm{g} / \mathrm{ml}$. In hot aqueous extract, the changes occurred at the highest concentration $(1000 \mu \mathrm{g} / \mathrm{ml})$ tested. MRC5 cells showed insensitive reactions to hot aqueous extract of $D$. mellea. The extract triggered proliferation rate at the highest confluent level, causing cytotoxicity effect on A549 cells. Selective ability of hot aqueous extract could be related to inhibition of mitochondrial Complex 1, where a class of therapeutic drugs like lipophilic compounds tended to inhibit mitochondrial bioenergetics, mitochondrial respiration in tumour cells at relatively nontoxic concentrations [36]. Changes in morphological appearance of cells observed as cell death were a reliable basis indicator that cells were undergoing process of apoptosis [37]. This apoptosis is a physiological program which eliminates cells by disrupting morphological and physiological characteristics of cells shrinkage, chromatin condensation, internucleosomal DNA fragmentation, and formation of apoptotic bodies. This has been an approach used in establishing cytotoxic effects of most anticancer agents [30, 38, 39].

\section{Conclusions}

The present study concludes that hot aqueous extract of D. mellea was sufficiently safe for human consumption at the cellular level. Hot aqueous extract had shown acute anticancer effects at a concentration of $1000 \mu \mathrm{g} / \mathrm{ml}$. Cold aqueous extract of the fungus had anticancer potential as shown by its significant cytotoxic effect against A549 cells. The study shows that MRC5 cells had excellent survival performance when treated with hot and cold aqueous extracts. Further investigation through in vivo cytotoxicity studies, which will validate the edibility and toxicity of this mushroom before being used for human consumption, is particularly crucial. The exploration effort at further unveiling the capability of $D$. mellea is strongly recommended. The anticancer capabilities of $D$. mellea need to be further investigated in various cancer types and stages, exploiting the mushrooms' full potential as a new alternative in pharmacological and medicinal applications.

\section{Data Availability}

All data used to support the findings of the present study are included within the article.

\section{Conflicts of Interest}

The authors declare that there are no conflicts of interest in the publication of this paper.

\section{Acknowledgments}

The authors of this study would like to thank Agro-Biotechnology Institute Malaysia (ABI) for providing facilities for the experiments and Universiti Putra Malaysia for financial support under Graduate Research Fellowship (GRF). This work was supported by the Ministry of Higher Education, Malaysia, and Universiti Putra Malaysia (GP-IPM/2016/ 947200).

\section{References}

[1] S. S. Lee, S. A. Alias, E. B. G. Jones, N. Zainuddin, and H. T. Chan, "Checklist of Fungi of Malaysia," Research Pamphlet, No. 132, Forest Research Institute Malaysia (FRIM), Institute of Ocean and Earth Sciences University of Malaya (IOES), Ministry of Natural Resources and Environment (MNRE), Malaysia Swan Printing Sdn. Bhd., Selangor, Malaysia, 2012.

[2] S. S. Lee, E. Horak, S. A. Alias et al., Checklist of Literature on Malaysian Macrofungi; Clearing House Mechanism (CHM), Retrieved from website: http://www.chm.frim.gov.my/ backup/Checklist_final.pdf, 2007.

[3] G. C. Wakchaure, "Production and marketing of mushrooms: global and national scenario," in Mushrooms-Cultivation, Marketing and Consumption, pp. 15-22, Directorate of Mushroom Research, India, 2011.

[4] S. Patel and A. Goyal, "Recent developments in mushrooms as anti-cancer therapeutics: a review," 3 Biotech, vol. 2, no. 1, pp. 1-15, 2012.

[5] M. Rai, G. Tidke, and S. P. Wasser, "Therapeutic potential of mushrooms," Natural Product Radiance, vol. 4, no. 4, pp. 246-257, 2005.

[6] M. Jayachandran, J. Xiao, and B. Xu, "A critical review on health promoting benefits of edible mushrooms through gut microbiota," International Journal of Molecular Sciences, vol. 18, no. 9, p. 1934, 2017.

[7] M. Joshi and A. Sgar, "In vitro free radical scavenging activity of a wild edible mushrooms, Sparassis crispa (Wulf) Fr., from north western Himalaya, India," Journal Mycology, vol. 2014, no. 1, Article ID 748531, 2014.

[8] I. Palacios, M. Lozano, C. Maro et al., "Antioxidant properties of phenolic compounds occurring in edible mushroom," Food Chemistry, vol. 128, p. 674, 2011.

[9] U. Grienke, M. Zöll, U. Peintner, and J. M. Rollinger, "European medicinal polypores - a modern view on traditional uses," Journal of Ethnopharmacology, vol. 154, no. 3, pp. 564-583, 2014.

[10] H. Chen, T. Tian, H. Miao, and Y.-Y. Zhao, "Traditional uses, fermentation, phytochemistry and pharmacology of Phellinus linteus: a review," Fitoterapia, vol. 113, pp. 6-26, 2016.

[11] W. Chen, H. Tan, Q. Liu et al., "A review: The bioactivities and Pharmacological Applications of Phellinus linteus," Molecules, vol. 24, no. 1888, pp. 1-24, 2019.

[12] F. Badria, H. Fathy, A. Fatehe, D. Elimam, and M. Ghazy, "Evaluate the cytotoxic activity of honey, propolis, and bee venom from different localities in Egypt against liver, breast, and colorectal cancer," Journal of Apitherapy, vol. 2, no. 1, pp. 1-8, 2017.

[13] L. J. McGaw, E. E. Elgorashi, and J. N. Eloff, "Cytotoxicity of African medicinal plants against normal animal and human cells," Toxicological Survey of African Medicinal Plants, vol. 8, pp. 181-233, 2014.

[14] P. Matilla, K. Suonpaa, and V. Piironen, "Functional properties of edible mushrooms," Nutrition, vol. 16, pp. 694-696, 2000.

[15] P. Kalac, "A review of chemical composition and nutritional value of wild-growing and cultivated mushrooms," Journal of 
the Science of Food and Agriculture, vol. 93, no. 2, pp. 209-218, 2013.

[16] N. I. P. Samsudin and N. Abdullah, "Edible mushrooms from Malaysia; a literature review on their nutritional and medicinal properties," International Food Research Journal, vol. 26, no. 1, pp. 11-31, 2019.

[17] S. P. Waster, "Medicinal mushrooms as a source of antitumor and immunomodulating polysaccharides," Applied Microbiology and Biotechnology, vol. 60, no. 3, pp. 258-274, 2002.

[18] S. Vikineswary and S. T. Chang, "Edible and medicinal mushrooms for sub-health intervention and prevention of lifestyle diseases," Asia Pacific Tech Monitor Jul-Sep, vol. 2013, pp. 33-43, 2013.

[19] A. Dundar, V. Okumus, S. Odzemir et al., "Antioxidant, antimicrobial, cytotoxic and anticholinesterase activities of seven mushrooms species with their phenolic acid composition," Journal of Horticulture, vol. 2, no. 4, pp. 1-7, 2015.

[20] N. A. M. Omar, N. Abdullah, U. R. Kuppusamy, M. A. Abdulla, and V. Sabaratnam, "Nutritional composition, antioxidant activities and antiulcer potential of Lentinus squarrosulus (Mont.) mycelia extract," Evidence-Based Complementary and Alternative Medicine, vol. 2011, Article ID 539356, 8 pages, 2011.

[21] A. Takahashi, T. Agatsuma, M. Matsuda et al., "Russuphelin A, a new cytotoxic substance from the mushroom Russula subnigricans Hongo," Chemical \& Pharmaceutical Bulletin, vol. 40, no. 12, pp. 3185-3188, 1992.

[22] Y.-L. Lee, G.-W. Huang, Z.-C. Liang, and J.-L. Mau, "Antioxidant properties of three extracts from Pleurotus citrinopileatus," LWT - Food Science and Technology, vol. 40, no. 5, pp. 823-833, 2007.

[23] Y. H. Tseng and J. L. Mau, "Antioxidant properties of cold water extracts from Ganoderma tsugae," Fungi Science, vol. 22, no. 1\&2, pp. 13-23, 2007.

[24] T. Mosmann, "Rapid colorimetric assay for cellular growth and survival: application to proliferation and cytotoxicity assays," Journal of Immunological Methods, vol. 65, no. 1-2, pp. 55-63, 1983.

[25] M. Zhang, S. W. Cui, P. C. K. Cheung, and Q. Wang, "Antitumor polysaccharides from mushrooms: a review on their isolation process, structural characteristics and antitumor activity," Trends in Food Science and Technology, vol. 18, no. 1, pp. 4-19, 2007.

[26] N. A. M. Jamil, N. M. N. Rashid, M. H. A Hamid, M. Rahmad, and J. R. Al-Obaidi, "Comparative nutritional and mycochemical contents, biological activities and LC/MS screening of tuber from new recipe cultivation technique with wild type tuber of tiger's milk mushroom of species Lignosus rhinoceros," World Journal of Microbiology and Biotechnology, vol. 34, p. 1, 2018.

[27] C. K. M. Lai, K.-H. Wong, and P. C. K. Cheung, "Antiproliferative effects of sclerotial polysaccharides from Polyporus rhinocerus Cooke (Aphyllophoromycetideae) on different kinds of leukemic cells," International Journal of Medicinal Mushrooms, vol. 10, no. 3, pp. 255-264, 2008.

[28] B. F. Lau, N. Abdullah, N. Aminudin, and H. B. Lee, "Chemical composition and cellular toxicity of ethnobotanical-based hot and cold aqueous preparations of the tiger's milk mushroom (Lignosus rhinocerotis)," Journal of Ethnopharmacology, vol. 150, no. 1, pp. 252-262, 2013.

[29] F.-F. Wang, C. Shi, Y. Yang, Y. Fang, L. Sheng, and N. Li, "Medicinal mushroom Phellinus igniarius induced cell apoptosis in gastric cancer SGC-7901 through a mitochondria- dependent pathway," Biomedicine and Pharmacotherapy, vol. 102, pp. 18-25, 2018.

[30] T. P. Smina, B. Nitha, T. P. A. Devasagayam, and K. K. Janardhanan, "Ganoderma lucidum total triterpenes induce apoptosis in MCF-7 cells and attenuate DMBA induced mammary and skin carcinomas in experimental animals," Mutation Research/Genetic Toxicology and Environmental Mutagenesis, vol. 813, pp. 45-51, 2017.

[31] M. Kozarski, A. Klaus, M. Niksic, D. Jakovljevic, J. P. F. G. Helsper, and L. J. L. D. Van Griensven, "Antioxidative and immunomodulating activities of polysaccharide extracts of the medicinal mushrooms Agaricus bisporus, Agaricus brasiliensis, Ganoderma lucidum and Phellinus linteus," Food Chemistry, vol. 129, no. 4, pp. 1667-1675, 2011.

[32] S.-Y. Tsai, T.-P. Wu, S.-J. Huang, and J.-L. Mau, "Antioxidant properties of ethanolic extracts from culinary-medicinal button mushroom Agaricus bisporus (J. Lange) Imbach (Agaricomycetideae) harvested at different stages of maturity," International Journal of Medicinal Mushrooms, vol. 10, no. 2, pp. 127-137, 2008.

[33] S. Shao, M. Hernandez, J. K. G. Kramer, D. L. Rinker, and R. Tsao, "Ergosterol profiles, fatty acid composition, and antioxidant activities of button mushrooms as affected by tissue part and developmental stage," Journal of Agricultural and Food Chemistry, vol. 58, no. 22, pp. 11616-11625, 2010.

[34] S. Lee, S. Lee, H.-S. Roh et al., "Cytotoxic constituents from the sclerotia of Poria cocos against human lung adenocarcinoma cells by inducing mitochondrial apoptosis," Cells, vol. 7, no. 9, p. 116, 2018.

[35] S. H. Kim, R. Jakhar, and S. C. Kang, "Apoptotic properties of polysaccharide isolated from fruiting bodies of medicinal mushroom Fomes fomentarius in human lung carcinoma cell line," Saudi Journal of Biological Sciences, vol. 22, no. 4, pp. 484-490, 2015.

[36] B. Kalyanaraman, G. Cheng, M. Hardy et al., "A review of the basics of mitochondrial bioenergetics, metabolism, and related signaling pathways in cancer cells: therapeutic targeting of tumor mitochondria with lipophilic cationic compounds," Redox Biology, vol. 14, pp. 316-327, 2018.

[37] U. Ziegler and P. Groscurth, "Morphological features of cell death," Physiology, vol. 19, no. 3, pp. 124-128, 2004.

[38] S. D. Ray, N. Yang, S. Pandey, N. T. Bello, and J. P. Gray, "Apoptosis," Reference Module in Biomedical Sciences, pp. 1$11,2019$.

[39] S. W. Fesik, "Promoting apoptosis as a strategy for cancer drug discovery," Nature Reviews Cancer, vol. 5, no. 11, pp. 876-885, 2005. 